\title{
ANALISIS TINGKAT PENDAPATAN USAHA TANI TOMAT APEL DI KECAMATAN TOMPASO KABUPATEN MINAHASA
}

\author{
Antonius Y. Luntungan \\ Fakultas Ekonomi Universitas Sam Ratulangi
}

\begin{abstract}
ABSTRAK
Penelitian ini dilakukan di Kecamatan Tompaso Kabupaten Minahasa, data yang digunakan adalah data primer dari petani respondenpada tiga desa yaitu Desa Kamanga, Desa Touure dan Desa Tonsewer, metode yang dipakai adalah observasi dan wawancara dan analisis yang digunakan adalah analisis tabel dan analisis regresi berganda.

Berdasarkan hasil penelitian menunjukkan bahwa jumlah produksi tomat apel mempunyai mengaruh positif yang signifikan terhadap tingkat pendapatan usahatani tomat apel pada tingkat $\alpha=0,01$. Besarnya pengaruh atau elastisitas variabel ( jumlah produksi tomat apel) terhadap variabel terikat (pendapatan usahatani tomat apel) yaitu 21814.809, biaya produksi tomat menunjukan tanda negatif dan mempunyai pengaruh yang signifikan terhadap pendapatan usahatani tomat apel pada tingkat $\alpha=$ 0,01. Besarnya pengaruh atau elastisitas biaya tomat apel terhadap pendapatan usahatani tomat adalah - 1305,644 berarti apabila biaya produksi tomat berkurang dari $1 \%$ maka pendapatan usahatani tomat turun sebesar - 1305,644 \% ceteris paribus dengan asumsi faktor-faktor lain dianggap tetap.
\end{abstract}

\section{PENDAHULUAN}

Dalam upaya meningkatkan pendapatan petani dan kelangsungan hidup masyarakat pada umumnya maka pemerintah menetapkan kebijaksanaan dan pedoman untuk mengusahakan tanaman yang berupa tanaman pangan yang mempunyai nilai ekonomis untuk meningkatkan pendapatan petani dan jenis tanaman yang memberikan kesempatan kerja lebih banyak serta jenis tanaman yang bernilai gizi tinggi. Karena sumber utama pendapatan penduduk miskin adalah sebagian besar berasal dari sektor pertanian maka pengentasan kemiskinan dengan memperbanyak kegiatan di sektor pertanian sangatlah strategis, yaitu pemanfatan lahan pertanian yang subur untuk ditanami tanaman pangan. (Soekartawi,1995).

Pembangunan pertanian dapat dilaksanakan dangan jalan menyempurnakan pola usahatani yang sudah ada dengan dilandasi oleh penerapan tekhnologi pertanian dan rehabilitasi lahan guna memenuhi kebutuhan hidup keluarga petani.

Di Indonesia buah tomat (Lycopersicum esculentum Mill) sangat digemari, karena rasanya enak, baik untuk dimakan segar, dibuat salad maupun untuk bumbu 
masak, bahkan tanaman ini mengandung vitamin $\mathrm{C}$, vitamin A (karoten) dan mineral. Konsumsi tomat segar dan olahan meningkat terus seiring dengan kebutuhan manusia pada gizi yang seimbang.

Kebutuhan minimum vitamin A dan vitamin $\mathrm{C}$ tiap orang dapat terpenuhi apabila tiap hari makan tomat sebanyak 100-300 gram. Akan tetapi sayuran dan buah-buahan lainnya merupakan sumbangan terhadap kebutuhan kita pula, sehingga apabila makan sayuran dan buah-buahan tersedia setiap hari telah cukup dapat menciptakan masyarakat yang sehat gizi. (Wiryanta,2002).

Selain konsumsi segar, buah tomat juga dimanfaatkan untuk berbagai industri misalnya sambal, saos, minuman, jamu, dan kosmetik. Sebagai bahan makanan, kandungan gizi buah tomat untuk terapi pengobatan alami, buah tomat berkhasiat untuk mencegah dan mengobati radang usus buntu, membantu penyembuhan luka, mengobati jerawat, mencegah pembentukan batu empedu pada saluran kencing, menjaga stamina dan mengobati penyakit yang disebabkan kekurangan vitamin $C$.

Kabupaten Minahasa berpeluang untuk pengembangan tanaman tomat sangat besar di tinjau dari sumber daya dan khususnya Kecamatan Tompaso merupakan daerah penghasil tomat apel atau sentra produksi tomat apel sehingga tanaman ini merupakan salah satu sumber pendapatan petani setiap tahunnya disamping pendapatan petani dari tanaman lainnya sebagai produk yang diusahakan oleh petani, sehingga produksi dan harga tomat apel sangat berperan penting dalam peningkatkan kesejahteraan petani.

Tabel 1.1 Luas Lahan dan Jumlah Produksi Tomat apel di Kecamatan

Tompaso Tahun 2009-2011

\begin{tabular}{|l|c|c|}
\hline Tahun & Luas Lahan Tanaman Tomat & Jumlah produksi (ton) \\
\hline 2009 & 128,27 & 25 \\
\hline 2010 & 175 & 84 \\
\hline 2011 & 225,54 & 178 \\
\hline Jumlah & 528,81 & 287 \\
\hline
\end{tabular}

Harga dan pendapatan produksi yang mempengaruhi usahatani tanaman tomat apel tersebut, maka latar belakang yang mendorong penulis untuk meneliti keberadaan usahatani ini adalah adanya kenyataan tentang tingkat hidup masyarakat di Kecamatan Tompaso yang pada beberapa tahun terakhir ini nampak mengalami perkembangan. Hal ini dapat di lihat pada perkembangan sektor pertanian, khususnya tanaman tomat apel tidak hanya ditujukan pada peningkatan produksi saja, tetapi juga merupakan upaya untuk memperoleh manfaat berupa peningkatan pendapatan dan 
kesejahteraan bagi petani itu sendiri serta memberi manfaat bagi lingkungan sekitarnya.

Tabel 1.2 Harga Tomat dan Pemasarannya

\begin{tabular}{|l|l|l|}
\hline No & Cara Memasarkan & Harga Tomat (Rp/krat) \\
\hline 1 & $\begin{array}{l}\text { Di jual langsung pada pedagang Rp. 55.000 } \\
\text { pengumpul }\end{array}$ \\
\hline 2 & $\begin{array}{l}\text { Di jual langsung ke pasar (pasar Rp. 50.000 } \\
\text { langowan) }\end{array}$ \\
\hline
\end{tabular}

Sumber : BPP Kecamatan Tompaso 2011

Sebagai produk yang banyak diusahakan oleh petani di Kecamatan Tompaso, harga tomat apel sangatlah berperan penting dalam meningkatkan kesejahteraan petani. Harga ini yang menjadikan faktor dimana petani di daerah ini masih tetap bertahan untuk mengusahakan tanaman tomat apel, sehingga secara tidak langsung dapat meningkatkan pendapatan petani itu sendiri.

\subsection{Perumusan Masalah}

Berdasarkan uraian di atas, maka dirumuskan masalah dalam penelitian ini

" Bagaimana tingkat pendapatan yang diterima petani dari usahatani tomat apel di Kecamatan Tompaso Kabupaten Minahasa”.

\subsection{Tujuan Dan Manfaat Penelitian}

Dalam penelitian ini bahwa pendapatan petani ditentukan oleh adanya imbalan-imbalan jasa dari komponen-komponen pemasaran hasil pertanian yang teratur dengan kesediaan harga konsumen sebagai imbalan jasa yang diterima petani, maka hal ini peneliti mengemukakan tujuan dan manfaat penelitian yaitu:

\subsection{Tujuan penelitian}

Penelitian ini bertujuan untuk:

1. Mengetahui tingkat pendapatan yang diterima oleh petani tomat apel dalam setiap kali masa tanam di Kecamatan Tompaso Kabupaten Minahasa.

2. Mengetahui pengaruh jumlah produksi dan biaya produksi terhadap tingkat pendapatan usahatani tomat apel di Kecamatan Tompaso.

\subsection{Manfaat Penelitian}

Dari hasil penelitian ini diharapkan dapat menjadi bahan masukkan bagi pemerintah, pengusaha, petani dan peneliti juga sebagai bahan informasi bagi pihak 
yang berkepentingan dalam pengembangan suatu usahatani khususnya usahatani tomat.

\section{LANDASAN TEORI}

\subsection{Pengertian Usahatani}

Menurut Soekartawi (1995), ilmu usahatani biasanya diartikan sebagai ilmu yang mempelajari bagaimana seorang mengalokasikan sumberdaya yang ada secara efektif dan efisien untuk tujuan memperoleh keuntungan yang tinggi pada waktu tertentu. Dikatakan efektif bila petani atau produsen dapat mengalokasikan sumberdaya yang mereka miliki (yang dikuasai) sebaikbaiknya; dan dikatakan efisien bila pemanfaatan sumberdaya tersebut menghasilkan keluaran (output) yang melebihi masukan (input).

Hernanto (1993), mengemukakan bahwa ada empat unsur pokok yang menjadi pembentuk usahatani yaitu :

1. Tanah

Tanah merupakan salah satu pembentuk usahatani karena tanah merupakan tempat atau ruang bagi seluruh kehidupan di muka bumi ini baik manusia, hewan dan juga tumbuh-tumbuhan.

2. Tenaga kerja

Dalam usahatani tenaga kerja yang kita kenal ada tiga jenis yaitu tenaga kerja manusia, tenaga kerja hewan dan tenaga kerja mesin. Tenaga kerja didefinisikan sebagai daya dari manusia untuk menimbulkan rasa lelah yang dipergunakan untuk mengahasilkan benda ekonomi.

3. Modal

Dalam usahatani modal yang dimaksud adalah tanah, bangunanbangunan (gedung, kandang, lantai jemur, pabrik dan lain-lain), bahanbahan pertanian (pupuk, bibit, pestisida), piutang dan uang tunai.

4. Pengelolaan

Pengelolaan usahatani adalah kemampuan petani dalam menentukan, mengorganisasikan dan mengkoordinasikan faktor-faktor produksi sebagaimana yang diharapkan.

\subsection{Biaya Usahatani}

Biaya dalam pengertian ekonomi adalah semua bahan yang harus ditanggung untuk menyediakan barang agar siap dipakai oleh konsumen (Sudarsono, 1995). Menurut Soekartawi (1995), biaya usahatani biasanya diklasifikasikan menjadi dua, yaitu: 
1. Biaya tetap (fixed cost) adalah biaya yang relative jumlahnya dan terus dikeluarkan walaupun produksi yang diperoleh banyak atau sedikit. Jadi, besarnya biaya tetap ini tidak tergantung pada besar kecilnya biaya produksi yang diperoleh. Biaya ini terdiri dari pajak dan penyusutan alat produksi.

2. Biaya Variabel (variable cost) adalah biaya yang besar kecilnya dipengaruhi oleh produksi yang diperoleh. Biaya ini terdiri dari biaya produk, pemeliharaan, bibit, pupuk, pestisida, biaya panen dan lain-lain.

\subsection{Pengertian Produksi}

Menurut Sukirno (2002) teori produksi menerangkan sifat hubungan di antara tingkat produksi yang akan dicapai dengan jumlah faktor-faktor produksi yang digunakan. Teori produksi dalam ilmu ekonomi membedakan analisisnya kepada pendekatan berikut:

1. Teori Produksi dengan satu faktor perubah.

Teori produksi yang sederhana menggambarkan tentang hubungan diantara tingkat produksi suatu barang dengan jumlah tenaga kerja yang digunakan untuk menghasilkan berbagai tingkat produksi barang tersebut. Dalam analisis tersebut dimisalkan bahwa faktor-faktor produksi lainnya adalah tetap jumlahnya yaitu modal dan tanah jumlahnya dianggap tidak mengalami perubahan. Satu-satunya faktor produksi yang diubah jumlahnya adalah tenaga kerja.

2. Teori Produksi dengan dua faktor berubah

Di dalam analisis yang berikut ini dimisalkan terdapat dua jenis faktor produksi yang dapat diubah jumlahnya misalnya yang dapat diubah adalah tenaga kerja dan modal. Misalkan pula bahwa dua faktor produksi yang dapat berubah ini dapat dipertukar-tukarkan penggunaannya; yaitu tenaga kerja dapat menggantikan modal atau sebaliknya, apabila misalkan pula harga tenaga kerja dan pembayaran per unit kepada faktor modal diketahui, analisis tentang bangunan perusahaan akan membingungkan biaya dalam usahanya untuk mencapai suatu tingkat produksi tertentu dapat ditunjukan.

\subsection{Biaya Produksi}

Biaya produksi dapat di bagi menjadi dua yaitu biaya-biaya yang berupa uang tunai misalnya upah kerja untuk biaya persiapan/penggarapan, tanah termasuk upah untuk ternak, biaya untuk membeli pupuk dan pestisida dll.

Biaya-biaya panen, bagi hasil, sumbangan dan mungkin juga pajak-pajak. Besar kecilnya bagian biaya produksi yang berupa uang tunai ini sangat mempengaruhi pengembangan usahatani. Penggunaan bibit-bibit unggul memerlukan 
biaya dalam jumlah besar dari pada bibit lokal, hal ini disebabkan karena bibit unggul lebih menguntungkan apabila diolah lebih baik.

Selain penggolongan di atas, jenis-jenis biaya produksi dapat pula dibagi dalam biaya tetap dan biaya variabel. Biaya tetap adalah jenis biaya yang besar kecilnya tidak tergantung pada besar kecilnya biaya produksi misalnya sewa atau bunga tanah yang berupa uang.

Biaya lain-lain umumnya masuk pada biaya variabel karena besar kecilnya berhubungan dengan besar produksi misalnya pengeluaranpengeluaran untuk bibit, biaya persiapan dan biaya pengolahan tanah.

\subsection{Hipotesa}

Berdasarkan latar belakang permasalahan dan tinjauan pustaka maka hopotesis dalam penelitian ini yaitu diduga bahwa tingkat pendapatan usahatani tomat apel di Kecamatan Tompaso dipengaruhi oleh jumlah produksi, biaya produksi dan harga tomat apel.

\section{METODE PENELITIAN}

\subsection{Data dan Sumber Data}

Data yang dipergunakan dalam penelitian ini adalah data primer dan data sekunder.

\subsection{Metode Pengumpulan Data}

Adapun metode pengumpulan data yang diambil sehubungan dengan penelitian ini adalah melalui metode observasi di daerah tempat penelitian dan wawancara langsung dengan menggunakan daftar pertanyaan yang telah disiapkan kepada petani tomat apel di Kecamatan Tompaso Kabupaten Minahasa.

\subsection{Metode Pengambilan Sampel}

Metode pengambilan sampel dalam penelitian ini adalah dengan menggunakan metode purposive sampling yaitu pengambilan sampel secara sengaja yang diambil di 3 desa sampel di Kecamatan Tompaso yang merupakan sentra produksi tanaman tomat yaitu desa Kamanga, desa Touure dan desa Tonsewer yang menjadi sampel adalah 60 responden. 


\subsection{Metode Analisis}

Metode analisis yang digunakan dalam penelitian ini adalah metode analisis tabel dan metode analisis regresi berganda, dengan menggunakan rumus sebagai berikut :

$$
\mathbf{Y}=\mathbf{a}+\mathbf{b x}+\mathbf{e}
$$

yang di transformasikan ke dalam bentuk ganda sebagai berikut :

$$
Y=b o+b 1 \times 1+b 2 \times 2+e i
$$

Dimana :

$$
\begin{aligned}
\mathbf{Y}= & \text { Pendapatan petani yang melakukan usahatani tomat } \\
\mathbf{X 1}= & \text { Jumlah produksi tomat } \\
\mathbf{X} 2= & \text { Biaya produksi } \\
\text { bo = } & \text { Intercept yang menggambarkan pengaruh rata-rata semua } \\
& \text { variabel jumlah produksi dan biaya produksi }(\mathbf{x}) \text { terhadap } \\
& \text { variabel pendapatan petani yang melakukan usahatani tomat } \\
& (\mathbf{y}) . \\
\text { b1-2 = } & \text { Koefisien regresi parsial masing-masing variabel X1-2 } \\
\text { ei }= & \text { Faktor pengganggu atau galat }
\end{aligned}
$$

a. Ditentukan berdasarkan rumus :

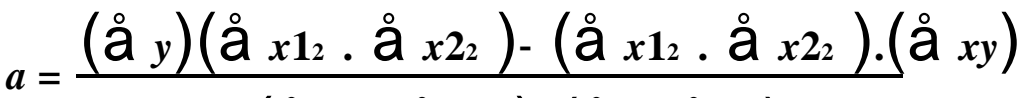

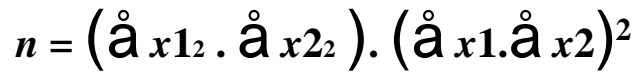

Dihitung dengan rumus :

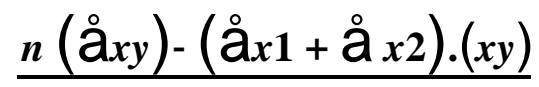

$$
\begin{aligned}
& b=n\left(\text { å } x 1_{2}+\text { å } x 2_{2}\right)-(\text { å } y)^{2}
\end{aligned}
$$

\subsection{Koefisien Korelasi}

Koefesien korelasi parsial digunakan untuk melihat derajat hubungan antara variabel bebas dengan variabel terikat secara simultan maupun secara parsial. Jika koefisien korelasi (r) mendekati 1 atau $100 \%$ maka derajat hubungan sangat kuat sedangkan jika koefisien korelasinya (r) mendekati 0 (nol) maka derajat hubungannya sangat lemah.

\subsection{Perumusan Hipotesis}

Perumusan hipotesis secara statistik serta parsial adalah sebagai berikut :

Ho : b1 = $0 \quad$; Jumlah produksi tomat tidak berpengaruh terhadap tingkat pendapatan usahatani tomat 
Ho : b1 $\neq 0 \quad ;$ Jumlah produksi tomat berpengaruh terhadap tingkat pendapatan usahatani tomat

Ho : b2 = $0 \quad$; Biaya produksi tidak berpengaruh terhadap tingkat pendapatan usahatani tomat

Ho : $\mathbf{b 2} \neq 0 \quad$; Biaya produksi berpengaruh terhadap tingkat pendapatan usahatani tomat

Untuk menguji hipotesis secara parsial di gunakan rumus sebagai berikut :

$$
t=\frac{b 1-b 1}{S b i}
$$

Dimana apabila :

- $\quad t$ hit $<\mathrm{t}$ tabel ( 0,05 ) maka Ho diterima sehingga H1 ditolak

- $\quad t$ hit > t tabel ( 0,05 ) maka Ho ditolak sehingga H1

diterima Perumusan hipotesis secara simultan

Ho : $\beta 1, \beta 2=0$ (jumlah produksi tomat dan biaya produksi tidak berpengaruh terhadap tingkat pendapatan usahatani tomat di kecamatan langowan barat )

Ho $: \beta 1, \beta 2 \neq 0 \quad$ ( jumlah produksi tomat dan biaya produksi berpengaruh terhadap tingkat pendapatan usahatani tomat di kecamatan langowan barat )

Untuk menguji hipotesis secara simultan digunakan rumus sebagai berikut :

$$
F=\frac{b_{1} \text { å1y- } b_{2} \text { å2y- } y / k-1}{Y_{2}-b_{1} \text { å } x 1 y-b_{2} \grave{a} x_{2} y-a ̊ y / n-K}
$$

Dimana :

$$
\begin{aligned}
& \mathbf{K} \text { = Banyaknya variabel } \\
& \mathbf{n}=\text { Banyaknya sampel }
\end{aligned}
$$

Dimana apabila :

F hitung < F tabel $(0,05)$, maka Ho diterima hingga H1 ditolak F

hitung > F tabel $(0,05)$, maka Ho ditolak hingga $\mathrm{H1}$ diterima

\subsection{Koefisien Determinasi}

Koefisien determasi ( R2) adalah memperkirakan konstribusi variabel bebas yaitu jumlah produksi tomat (X1) dan biaya produksi (X2) terhadap naik turunya variabel terikat ( tingkat pendapatan usahatani tomat (Y) ) dengan menggunakan rumus koefisien determinasi sebagai berikut :

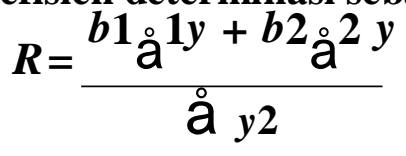


Bila $R 2=1$, berarti persentase sumbangan jumlah produksi tomat (X1) dan biaya roduksi (X2) terhadap naik turunya Y sebesar $100 \%$ dan tidak ada faktor lain yang mempengaruhi variabel $Y$.

Bila $\mathrm{R} 2=0$, berarti regresi yang tidak digunakan untuk membuat ramalan terhadap Y.

\subsection{Definisi pengukuran variabel}

Dalam penelitian ini dikemukakan definisi dari variabel yang digunakan yaitu:

- Pendapatan adalah jumlah penerimaan petani yang melakukan usahatani tomat apel dikurangi dengan biaya produksi yang diukur dengan satuan rupiah ( $R \mathbf{p})$.

- Jumlah produksi adalah besarnya produksi tomat apel yang dihasilkan petani dalam sekali tanam yang diukur dengan satuan kilogram (Kg).

- Biaya produksi adalah besarnya biaya yang dikeluarkan petani dalam melakukan penanaman tomat apel dalam sekali tanam yang diukur dalam satuan rupiah ( $R p)$.

- Harga produksi adalah harga tomat apel yang berlaku dipasaran yang di ukur dalam satuan rupiah (Rp).

\section{HASIL DAN PEMBAHASAN}

\subsection{Hasil Penelitian}

4.1.1. Lokasi

Kecamatan Tompaso merupakan daerah penghasil tomat apel atau sentra produksi tomat apel sehingga tanaman ini merupakan salah satu sumber pendapatan petani setiap tahunnya disamping pendapatan petani dari tanaman lainnya sebagai produk yang diusahakan oleh petani.

Dalam penelitian ini responden yang dipakai sebagai sampel dari tiga desa seperti pada tabel berikut ini :

Tabel 4.1. Klasifikasi Jumlah Responden Menurut Asal Desa/Kelurahan di Kecamatan Tompaso

\begin{tabular}{|l|l|l|l|}
\hline No & Asal Desa/Kelurahan & Jumlah Responden & Persentase \\
\hline 1 & Kamanga & 20 & 33,34 \\
\hline 2 & Touure & 20 & 33,34 \\
\hline 3 & Tonsewer & 20 & 33,34 \\
\hline & Jumlah & 60 & 100 \\
\hline
\end{tabular}


Sumber : Diolah dari hasil penelitian, 2011

Dari tabel di atas dijelaskan bahwa 60 responden sample yang diteliti, diambil tiga desa dari keseluruhan/ desa yang ada di Kecamatan Tompaso.

\subsubsection{Responden Menurut Tingkat Pendidikan}

Tingkat pendidikan seorang petani dapat mempengaruhi produktifitasnya di dalam mengelolah usahataninya di Kecamatan Tompaso pada tabel berikut ini :

Tabel 4.2. Klasifikasi Jumlah Responden Menurut Tingkat Pendidikan di Kecamatan Tompaso

\begin{tabular}{|c|l|c|c|}
\hline No & Tingkat Pendidikan & Jumlah Responden & Persentase \\
\hline 1 & Tidak Tamat SD & 4 & 6,66 \\
\hline 2 & SD & 10 & 16,67 \\
\hline 3 & SMP & 10 & 16,67 \\
\hline 4 & SMU & 30 & 50 \\
\hline 5 & SARJANA/S1 & 6 & 10 \\
\hline & Jumlah & 60 & 100 \\
\hline
\end{tabular}

Sumber : Diolah dari hasil penelitian,2011

Dari tabel di atas dapat dilihat bahwa dari keseluruhan responden yang diteliti terdapat 4 responden $(6,66 \%)$ tidak tamat SD, 10 responden $(16,67 \%) \mathrm{SD}, 10$ responden $(16,67 \%)$ SMP, 30 responden (50\%) SMA. Dari tabel di atas pula terdapat responden yang tingkat pendidikannya lebih tinggi yaitu Sarjana 6 responden $(10 \%)$. Petani yang sudah berpindidikan tinggi yang artinya bahwa petani-petani tersebut adalah petani yang sudah cukup maju dari segi pendidikan.

\subsubsection{Responden menurut jenis pekerjaan sampingan}

Untuk memenuhi kebutuhan hidup banyak dari petani memiliki pekerjaan lebih dari satu untuk atau pekerjaan sampingan agar dapat lebih meningkatkan pendapatan, seperti dalam tabel berikut :

Tabel 4.3. Klasifikasi Pekerjaan Sampingan Responden

\begin{tabular}{|c|l|c|c|}
\hline No & \multicolumn{1}{|c|}{ Jenis Pekerjaan } & Responden & Persentase \\
\hline 1 & Petani sawah ladang & 30 & 50 \\
\hline 2 & Tukang & 15 & 25 \\
\hline 3 & Buruh & 10 & 16,67 \\
\hline
\end{tabular}




\begin{tabular}{|l|l|c|c|}
\hline 4 & Tidak mempunyai pekerjaan sampingan & 5 & 8,33 \\
\hline & Jumlah & 60 & 100 \\
\hline
\end{tabular}

Berdasarkan tabel di atas bahwa sebagian besar responden yang diteliti memiliki pekerjaan sampingan.

Berikut ini jumlah pendapatan tiap bulan para petani tomat apel yang memiliki pendapatan sampingan.

Tabel 4.4. Klasifikasi Pendapatan Pekerjaan Sampingan Responden

\begin{tabular}{|l|c|c|}
\hline \multicolumn{1}{|c|}{ Interval Pendapatan (Rp) } & Jumlah Responden & Persentase \\
\hline $\mathbf{2 5 0 . 0 0 0 - 5 0 0 . 0 0 0}$ & 7 & 11,67 \\
\hline $\mathbf{5 0 0 . 0 0 0 - 7 5 0 . 0 0 0}$ & 15 & 25 \\
\hline $750.000-1.000 .000$ & 20 & 33,33 \\
\hline $1.000 .000-1.500 .000$ & 10 & 16,67 \\
\hline $1.500 .000-$ ke atas & 5 & 8,33 \\
\hline Tidak ada pendapatan sampingan & 3 & 5 \\
\hline Jumlah & 60 & 100 \\
\hline
\end{tabular}

Sumber : Diolah dari hasil penelitian,2011

\subsection{Pembahasan}

4.2.1. Luas lahan tanaman tomat petani responden

Luas lahan petani responden di Kecamatan Tompaso terdiri dari $<1$ ha adalah sebesar 1,5 ha atau sekitar 2,31\%, sedangkan lahan yang paling kecil yaitu 0,75 atau sekitar $1,15 \%$.

\subsubsection{Jumlah Produksi Tomat}

Jumlah produksi tomat apel di tiga desa sampel berdasarkan luas lahan dapat di lihat dalam tabel berikut ini : 
Tabel 4.5. Jumlah Produksi Tomat apel Berdasarkan Luas Lahan

\begin{tabular}{|c|c|c|c|}
\hline Responden & \multicolumn{3}{|c|}{ Jumlah produksi Tomat Apel / Krat } \\
\hline & Luas lahan $<1$ & Luas lahan $=1$ & Luas lahan $>1$ \\
\hline 1 & 200 & 350 & 400 \\
\hline 2 & 200 & 340 & 410 \\
\hline 3 & 150 & 350 & 375 \\
\hline 4 & 150 & 300 & 380 \\
\hline 5 & 160 & 325 & 385 \\
\hline 6 & 175 & 340 & 400 \\
\hline 7 & 200 & 350 & 450 \\
\hline 8 & 200 & 340 & 450 \\
\hline 9 & 150 & 330 & 500 \\
\hline 10 & 150 & 320 & 450 \\
\hline 11 & 175 & 310 & 410 \\
\hline 12 & 175 & 320 & 375 \\
\hline 13 & 175 & 340 & 380 \\
\hline 14 & 200 & 340 & 400 \\
\hline 15 & 200 & 300 & 420 \\
\hline 16 & 160 & 350 & 500 \\
\hline 17 & 160 & 325 & 400 \\
\hline 18 & 200 & 310 & 437 \\
\hline 19 & 200 & 350 & 400 \\
\hline 20 & 160 & 320 & 500 \\
\hline
\end{tabular}

Sumber : Diolah dari hasil penelitian,2011

Dari hasil penelitian di tiga desa sampel bahwa luas lahan $<1$ ha memproduksi tomat paling banyak yaitu sebanyak 200 krat dan paling sedikit yaitu hanya 150 krat, sedangkan luas lahan 1 ha memproduksi tomat paling banyak yaitu sebesar 350 krat dan paling sedikit adalah 300 krat dan luas lahan > 1 memproduksi tomat paling banyak 500 krat dan paling sedikit yaitu sebesar 375 krat.

\subsubsection{Biaya Produksi}

Biaya produksi yang dikeluarkan oleh petani dalam melakukan usahatani tomat apel untuk satu kali masa panen pada lahan $<1$ ha, =1 dan $>1$ ha adalah sebagai berikut :

- $\quad$ Lahan < 1 Ha

Biaya Produksi 
1. Benih 1,5 liter (@ Rp. 25.000)

Rp. $\quad 25.000$

2. Pengolahan Tanah

- Pembersihan ; 8 orang (@ Rp. 35.000)

- Pembuatan Bedeng ; 8 orang (@ Rp. 35.000)

Rp. 280.000

Rp. 280.000

3. Tanam

- Buat lobang tanam; 2 orang (@ Rp. 35.000)

Rp. $\mathbf{7 0 . 0 0 0}$

- Tanam ; 2 orang (@ Rp.35.000)

Rp. $\mathbf{7 0 . 0 0 0}$

- Pemupukan dasar; 2 orang (@ Rp.35.000)

Rp. $\mathbf{7 0 . 0 0 0}$

4. Pupuk

- Pupuk Kandang; 75 kali (@ Rp. 5000)

Rp. 375.000

- pupuk urea; 150 kg (@ Rp. 1400)

Rp. 210.000

- Pupuk SP36; 150 kg (@ Rp.1900)

Rp. 285.000

- Pupuk KCL 75 kg (@ Rp. 2000)

Rp. 150.000

- PPC 1,5 liter (@ Rp. 20.000)

Rp. $\quad 30.000$

5. Pestisida

- Insektision 1 liter (@ Rp. 180.000)

Rp. 180.000

- Fungisida 1 kg (@ Rp. 120.000)

Rp. 120.000

6. Penyiangan; 5 orang (@ Rp. 30.000)

Rp. 150.000

7. Pemupukan susulan ; 2 orang (@ Rp. 30.000)

Rp. $\quad 60.000$

8. Penyemprotan; 4 orang (@ Rp.30.000)

Rp. 120.000

9. Panen; Rp. 2500/krat ( 175 x 2500)

Rp. 437.000

10. Pengangkutan Rp. 2000/krat (175 x 2000)

Rp. 350.000

Jumlah

Rp.3.262.500

- $\quad$ Lahan = 1 ha

Biaya-biaya produksi

1. Benih 2,5 liter (a. Rp. 25.000)

Rp. $\quad 62.500$

2. Pengolahan

- Pembersihan ; 15 orang (a. Rp. 35.000)

Rp. $\mathbf{5 2 5 . 0 0 0}$

- Pembuatan bedeng (a. Rp. 35.000)

Rp. $\mathbf{5 2 5 . 0 0 0}$

3. Tanah

- Buat lobang tanam; 4 orang (a. Rp. 35.000)

Rp. 140.000

- Tanam; 4 orang (a. Rp. 35.000)

Rp. 140.000

- Pemupukan dasar; 4 orang (a. Rp. 35.000)

Rp. 140.000

4. Pupuk

- Pupuk kandang; 150 kali (a. Rp. 5000)

Rp. 750.000

- Pupuk urea; 300 kg (a. Rp. 1400)

Rp. 420.000

- Pupuk SP36; 300 kg (a. Rp. 1900)

Rp. $\mathbf{5 7 0 . 0 0 0}$ 
- Pupuk KCL; 75 kg (a. Rp. 2000)

- PPC; 3 liter (a. Rp. 20.000)

5. Pestisida

- Insektision; 2 liter (a. Rp. 180.000)

- Fungisida; 2 liter (a. Rp. 120.000)

6. Penyiangan; 13 orang (a. Rp. 30.000)

7. Pemupukan susulan; 4 orang (a. Rp. 30.000)

8. Penyemprotan ; 10 orang (a. Rp. 30.000)

9. Panen ; Rp. 2500/krat (2500X350)

10. Pengangkutan Rp. 2000/krat (2000X350) Jumlah
Rp. 150.000

Rp. $\quad 60.000$

Rp. 360.000

Rp. 240.000

Rp. 390.000

Rp. 120.000

Rp. 300.000

Rp. 875.000

Rp. 700.000

Rp.6.467.500

Rp. $\quad 87.500$

Rp. $\quad 980.000$

Rp. 980.000

- Pembuatan bedeng; 28 orang (a. Rp. 35.000)

3. Tanam

- Buat lobang tanam; 5 orang (a.Rp. 35.000)

Rp. 175.000

- Tanam; 5 orang (a. Rp. 35.000)

Rp. 175.000

Rp. 210.000

\section{Pupuk}

- Pupuk kandang; 225 kali (a. Rp. 5000)

Rp.1.125.000

- Pupuk urea; 500 kg (a. Rp. 1400)

Rp. $\mathbf{7 0 0 . 0 0 0}$

- Pupuk SP36; 500 kg (a. Rp. 1900)

Rp. $\quad 950.000$

Rp. $\quad \mathbf{5 7 0 . 0 0 0}$

Rp. $\quad \mathbf{1 0 0 . 0 0 0}$

- PPC; 5 liter (a. Rp. 20.000)

5. Pestisida

- Insektision; 3 liter (@ Rp. 180.000)

Rp. $\quad \mathbf{5 4 0 . 0 0 0}$

- Fungisida; 3 kg (@ Rp.120.000)

6. Penyiangan; 20 orang (@ Rp.30.000)

7. Pemupukan susulan; 10 orang (@ Rp. 30.000)

8. Penyemprotan; 17 orang (@ Rp. 30.000)

9. Panen Rp. 2500/krat (500 x 2500)

Rp. $\quad 360.000$

Rp. $\quad 600.000$

Rp. $\quad 300.000$

Rp. $\quad \mathbf{5 1 0 . 0 0 0}$

Rp.1.250.000

Rp.1.000.000

Rp.10.612.500 Jumlah 


\subsubsection{Harga Tomat}

Harga tomat yang berlaku di pasaran bervariasi tergantung dari cara pemasaran.

1. Di jual langsung di pasar Rp. 55.000/krat

2. Di jual langsung kepada pedangang perantara Rp. 50.000/krat.

\section{3. $\quad$ Tingkat Pendapatan Usahatani Tomat Apel}

Peningkatan pendapatan masyarakat berlangsung secara kumulatif dan berdampingan positif bagi kemajuan pembagunan karena jika pendapatan masyarakat naik, menyebabkan tabungan naik. Pendapatan yang diterima biasanya di gunakan untuk membiayai kehidupan sehari-hari, selain itu apabila ada saja pendapatan yang tidak habis digunakan dalam membiayai kebutuhannya maka sisa dana tersebut akan di gunakan untuk investasi atau tabungan.

\subsubsection{Pendapatan Bruto}

Untuk mengetahui nilai jual tomat atau pendapatan bruto dari masingmasing petani responden pada tiga desa sampel berdasarkan luas lahan dapat di lihat dalam tabel berikut:

Tabel 4.6. Jumlah Produksi Harga Rata-rata dan Nilai Jual Tomat apel Pada Luas Lahan $<1$ ha

\begin{tabular}{|c|c|c|c|}
\hline Respond en & Jumlah Produksi/krat & Harga Tomat Apel (Rp/ krat) & Pendapatan Bruto (Rp) \\
\hline 1 & 200 & 50.000 & 10.000 .000 \\
\hline 2 & 200 & 50.000 & 10.000 .000 \\
\hline 3 & 150 & 50.000 & 7.500 .000 \\
\hline 4 & 150 & 50.000 & 7.500 .000 \\
\hline 5 & 160 & 50.000 & 8.000 .000 \\
\hline 6 & 175 & 50.000 & 8.750 .000 \\
\hline 7 & 200 & 50.000 & 10.000 .000 \\
\hline 8 & 200 & 50.000 & 10.000 .000 \\
\hline 9 & 150 & 50.000 & 7.500 .000 \\
\hline 10 & 150 & 50.000 & 7.500 .000 \\
\hline 11 & 175 & 50.000 & 8.750 .000 \\
\hline 12 & 175 & 50.000 & 8.750 .000 \\
\hline 13 & 175 & 50.000 & 8.750 .000 \\
\hline 14 & 200 & 50.000 & 10.000 .000 \\
\hline 15 & 200 & 50.000 & 10.000 .000 \\
\hline 16 & 160 & 50.000 & 8.000 .000 \\
\hline 17 & 160 & 50.000 & 8.000 .000 \\
\hline 18 & 200 & 50.000 & 10.000 .000 \\
\hline 19 & 200 & 50.000 & 10.000 .000 \\
\hline 20 & 160 & 50.000 & 80.000 .000 \\
\hline
\end{tabular}

Sumber : Diolah dari hasil penelitian, 2011

Keterangan : 1 krat tomat $=15 \mathrm{~kg}($ ukuran $\mathrm{krat} 30 \times 30 \times 50 \mathrm{~cm})$.

Berdasarkan tabel di atas dapat diketahui bahwa luas lahan $<1$ ha menghasilkan tomat apel paling tinggi 200 krat dengan nilai jual Rp. 10.000.000 dam 
hasil produksi paling rendah 150 krat dengan nilai jual atau pendapatan bruto Rp. 7.500.000.

Tabel 4.7. Jumlah Produksi Harga Rata-Rata dan Nilai Jual Tomat apel Pada Lahan 1 ha

\begin{tabular}{|c|c|c|c|}
\hline Responden & Jumlah Produksi/ krat & Harga Tomat Apel (Rp/ krat) & Pendapatan Bruto (Rp) \\
\hline 1 & 350 & 50.000 & 17.500 .000 \\
\hline 2 & 340 & 50.000 & 17.000 .000 \\
\hline 3 & 350 & 50.000 & 17.500 .000 \\
\hline 4 & 300 & 50.000 & 15.000 .000 \\
\hline 5 & 325 & 50.000 & 16.250 .000 \\
\hline 6 & 340 & 50.000 & 17.000 .000 \\
\hline 7 & 350 & 50.000 & 17.500 .000 \\
\hline 8 & 340 & 50.000 & 17.000 .000 \\
\hline 9 & 330 & 50.000 & 16.500 .000 \\
\hline 10 & 320 & 50.000 & 16.000 .000 \\
\hline 11 & 310 & 50.000 & 15.500 .000 \\
\hline 12 & 320 & 50.000 & 16.000 .000 \\
\hline 13 & 340 & 50.000 & 17.000 .000 \\
\hline 14 & 340 & 50.000 & 17.000 .000 \\
\hline 15 & 300 & 50.000 & 15.000 .000 \\
\hline 16 & 350 & 50.000 & 17.500 .000 \\
\hline 17 & 325 & 50.000 & 16.250 .000 \\
\hline 18 & 310 & 50.000 & 15.500 .000 \\
\hline 19 & 350 & 50.000 & 17.500 .000 \\
\hline 20 & 320 & 50.000 & 16.000 .000 \\
\hline
\end{tabular}

Sumber : Diolah dari hasil penelitian, 2011

Tabel di atas menunjukan bahwa luas lahan 1 ha menghasilkan tomat paling tinggi 350 krat dengan nilai jual Rp. 17.500.000 dan hasil produksi paling rendah 300 krat dengan nilai jual Rp. 15.000.000. Dalam setahun biasanya petani memproduksi tomat 2-3 kali, pada luas lahan 1 ha petani memproduksi tomat dalam setahun paling tinggi 700 krat dan paling rendah 600 krat. 
Tabel 4.8. Jumlah Produksi Harga Rata-Rata dan Nilai Jumlah Tomat apel Pada Lahan > $1 \mathrm{Ha}$

\begin{tabular}{|c|c|c|c|}
\hline Responden & Jumlah Produksi/krat & Harga Tomat Apel (Rp/ krat) & Pendapatan Bruto (Rp) \\
\hline 1 & 400 & 50.000 & 20.000 .000 \\
\hline 2 & 410 & 50.000 & 20.500 .000 \\
\hline 3 & 375 & 50.000 & 18.750 .000 \\
\hline 4 & 380 & 50.000 & 19.000 .000 \\
\hline 5 & 385 & 50.000 & 19.250 .000 \\
\hline 6 & 400 & 50.000 & 20.000 .000 \\
\hline 7 & 450 & 50.000 & 22.500 .000 \\
\hline 8 & 450 & 50.000 & 22.500 .000 \\
\hline 9 & 500 & 50.000 & 25.000 .000 \\
\hline 10 & 450 & 50.000 & 22.500 .000 \\
\hline 11 & 410 & 50.000 & 20.500 .000 \\
\hline 12 & 375 & 50.000 & 18.750 .000 \\
\hline 13 & 380 & 50.000 & 19.000 .000 \\
\hline 14 & 400 & 50.000 & 20.000 .000 \\
\hline 15 & 420 & 50.000 & 21.000 .000 \\
\hline 16 & 500 & 50.000 & 25.000 .000 \\
\hline 17 & 400 & 50.000 & 20.000 .000 \\
\hline 18 & 437 & 50.000 & 21.850 .000 \\
\hline 19 & 400 & 50.000 & 20.000 .000 \\
\hline 20 & 500 & 50.000 & 25.000 .000 \\
\hline
\end{tabular}

Sumber : Diolah dari hasil penelitian, 2011

Tabel di atas menunjukan bahwa pada lahan $>1$ ha menghasilkan tomat paling tinggi 500 krat dengan nilai jual Rp. 25.000.000 dan hasil produksi paling rendah adalah 375 krat dengan nilai jual Rp. 18.750.000.

\subsubsection{Pendapatan Bersih}

Berdasarkan hasil penelitian menunjukan bahwa produksi yang dihasilkan oleh petani akan mempeoleh pendapatan dari penjual tomat apel tersebut dalam 1 kali masa panen. Untuk lebih jelasnya dapat di lihat jumlah pendapatan dari tiap responden di tiga desa sampel berdasarkan luas lahan pada tabel berikut : 
Tabel 4.9. Pendapatan Bersih Usahatani Tomat apel Dalam 1 Kali Masa Panen Pada Luas lahan $<1$

\begin{tabular}{|c|c|c|c|}
\hline Responden & Pendapatan Bruto/Rp & Biaya Produksi (Rp) & Pendapatan Bersih (Rp) \\
\hline 1 & 10.000 .000 & 3.262 .500 & 6.737 .500 \\
\hline 2 & 10.000 .000 & 3.262 .500 & 6.737 .500 \\
\hline 3 & 7.500 .000 & 3.262 .500 & 4.237 .500 \\
\hline 4 & 7.500 .000 & 3.262 .500 & 4.237 .500 \\
\hline 5 & 8.000 .000 & 3.262 .500 & 4.737 .500 \\
\hline 6 & 8.750 .000 & 3.262 .500 & 5.237 .500 \\
\hline 7 & 10.000 .000 & 3.262 .500 & 6.737 .500 \\
\hline 8 & 10.000 .000 & 3.262 .500 & 6.737 .500 \\
\hline 9 & 7.500 .000 & 3.262 .500 & 4.237 .500 \\
\hline 10 & 7.500 .000 & 3.262 .500 & 4.237 .500 \\
\hline 11 & 8.750 .000 & 3.262 .500 & 5.237 .500 \\
\hline 12 & 8.750 .000 & 3.262 .500 & 5.237 .500 \\
\hline 13 & 8.750 .000 & 3.262 .500 & 5.237 .500 \\
\hline 14 & 10.000 .000 & 3.262 .500 & 6.737 .500 \\
\hline 15 & 10.000 .000 & 3.262 .500 & 6.737 .500 \\
\hline 16 & 8.000 .000 & 3.262 .500 & 4.737 .500 \\
\hline 17 & 8.000 .000 & 3.262 .500 & 4.737 .500 \\
\hline 18 & 10.000 .000 & 3.262 .500 & 6.737 .500 \\
\hline 19 & 10.000 .000 & 3.262 .500 & 6.737 .500 \\
\hline 20 & 8.000 .000 & 3.262 .500 & 4.737 .500 \\
\hline Jumlah & 177.000 .000 & 65.250 .000 & 120.740 .000 \\
\hline & 8.850 .000 & 326.500 & 6.037 .000 \\
\hline
\end{tabular}

Sumber : Diolah dari hasil penelitian, 2011

Berdasarkan tabel di atas dapat diketahui bahwa pendapatan bersih usahatani tomat dengan luas lahan $<1$ ha yaitu pendapatan bersih yang paling besar Rp. 6.737.500,- dan pendapatan bersih paling rendah yaitu Rp. 4.237.500,- Pendapatan bersih usahatani tomat dari masing-masing responden dihasilkan dari pendapatan bruto (nilai jual) dikurangi dengan biaya produksi dan ratarata pendapatan bersih petani yang melakukan usahatani tomat pada luas lahan < 1 ha adalah Rp. 6.037.000,-. 
Tabel 4.10. Pendapatan Bersih Usahatani Tomat apel Dalam 1 Kali Masa Panen Pada Luas Lahan 1 ha

\begin{tabular}{|c|c|c|c|}
\hline Responden & Pendapatan Bruto (Rp) & Biaya Produksi (Rp) & Pendapatan Bersih (Rp) \\
\hline 1 & 17.500 .000 & 5.897 .500 & 11.602 .500 \\
\hline 2 & 17.500 .000 & 5.897 .500 & 11.602 .500 \\
\hline 3 & 17.500 .000 & 5.897 .500 & 11.602 .500 \\
\hline 4 & 15.000 .000 & 5.897 .500 & 9.102 .500 \\
\hline 5 & 16.250 .000 & 5.897 .500 & 10.352 .500 \\
\hline 6 & 17.000 .000 & 5.897 .500 & 11.102 .500 \\
\hline 7 & 17.500 .000 & 5.897 .500 & 11.602 .500 \\
\hline 8 & 17.500 .000 & 5.897 .500 & 11.102 .500 \\
\hline 9 & 16.500 .000 & 5.897 .500 & 10.602 .500 \\
\hline 10 & 16.500 .000 & 5.897 .500 & 10.102 .500 \\
\hline 11 & 15.500 .000 & 5.897 .500 & 9.602 .500 \\
\hline 12 & 16.000 .000 & 5.897 .500 & 10.102 .500 \\
\hline 13 & 17.000 .000 & 5.897 .500 & 11.102 .500 \\
\hline 14 & 17.000 .000 & 5.897 .500 & 11.102 .500 \\
\hline 15 & 15.000 .000 & 5.897 .500 & 9.102 .500 \\
\hline 16 & 17.500 .000 & 5.897 .500 & 11.602 .500 \\
\hline 17 & 16.250 .000 & 5.897 .500 & 10.352 .500 \\
\hline 18 & 15.500 .000 & 5.897 .500 & 9.102 .500 \\
\hline 19 & 17.500 .000 & 5.897 .500 & 11.102 .500 \\
\hline 20 & 16.000 .000 & 5.897 .500 & 10.102 .500 \\
\hline Jumlah & 331.000 .000 & 117.950 .000 & 221.540 .000 \\
\hline & 16.550 .000 & 5.897 .500 & 11.077 .000 \\
\hline
\end{tabular}

Sumber : Diolah dari hasil penelitian, 2011

Tabel di atas menunjukan bahwa pendapatan bersih usahatani tomat dengan luas lahan 1 ha, paling tinggi yaitu sebesar Rp. 7.032.500,- dan yang paling rendah yaitu $R$ p. 4.532.500,- dan rata-rata pendapatan bersih petani yang melakukan usahatani tomat pada luas lahan 1 ha adalah $R p .5 .780 .875,-$. 
Tabel 4.11. Pendapatan Bersih Usahatani Tomat apel dalam 1Kali Masa Panen Pada Luas Lahan > 1 Ha

\begin{tabular}{|c|c|c|c|}
\hline Responden & Pendapatan Bruto (Rp) & Biaya Produksi (Rp) & Pendapatan Bersih (Rp) \\
\hline 1 & 20.000 .000 & 10.362 .500 & 9.637 .500 \\
\hline 2 & 20.500 .000 & 10.362 .500 & 10.137 .500 \\
\hline 3 & 18.750 .000 & 10.362 .500 & 8.387 .500 \\
\hline 4 & 19.000 .000 & 10.362 .500 & 8.637 .500 \\
\hline 5 & 19.250 .000 & 10.362 .500 & 8.887 .500 \\
\hline 6 & 20.000 .000 & 10.362 .500 & 9.637 .500 \\
\hline 7 & 22.500 .000 & 10.362 .500 & 12.137 .500 \\
\hline 8 & 22.500 .000 & 10.362 .500 & 12.137 .500 \\
\hline 9 & 25.000 .000 & 10.362 .500 & 14.637 .500 \\
\hline 10 & 22.500 .000 & 10.362 .500 & 12.137 .500 \\
\hline 11 & 20.000 .000 & 10.362 .500 & 9.637 .500 \\
\hline 12 & 18.750 .000 & 10.362 .500 & 8.387 .500 \\
\hline 13 & 19.000 .000 & 10.362 .500 & 8.637 .500 \\
\hline 14 & 20.000 .000 & 10.362 .500 & 9.637 .500 \\
\hline 15 & 21.000 .000 & 10.362 .500 & 10.637 .500 \\
\hline 16 & 25.000 .000 & 10.362 .500 & 14.637 .500 \\
\hline 17 & 20.000 .000 & 10.362 .500 & 9.637 .500 \\
\hline 18 & 21.850 .000 & 10.362 .500 & 11.487 .500 \\
\hline 19 & 20.000 .000 & 10.362 .500 & 9.637 .500 \\
\hline 20 & 25.000 .000 & 10.362 .500 & 14.637 .500 \\
\hline Jumlah & 421.100 .000 & 207.250 .000 & 223.340 .000 \\
\hline & 21.055 .000 & 10.362 .500 & 11.167 .000 \\
\hline
\end{tabular}

Sumber : Diolah dari hasil penelitian, 2011

Tabel di atas menunjukan bahwa pendapatan bersih usahatani tomat dengan luas lahan $>1$ ha, paling tinggi sebesar yaitu Rp 14.387.500,- dan paling rendah yaitu Rp. 8.137.500,- dan rata-rata pendapatan bersih petani yang melakukan usahatani tomat pada luas lahan $>1$ ha adalah $R p$. 10.392.500,--

\subsection{Analisis Tingkat Pendapatan Usahatani Tomat apel}

Secara teoritis kenaikan pendapatan akan bertambah pula jumlah biaya. Dengan adanya kenaikan tingkat pendapatan ini secara tidak langsung akan menambah pendapatan negara pada umumnya dan sekaligus dengan kenaikan pendapatan ini akan menunjang pembangunan desa, daerah dan nasional, karena dengan pendapatannya maka petani mempunyai kemungkinan dan kesempatan yang lebih banyak untuk berpartisapasi dalam pembangunan.

Untuk mengetahui lebih lanjut mengenai pendapatan usahatani tomat, maka penulis menganalisis dengan analisis regresi berganda dan korelasi.

Dalam perhitungan regresi berganda jumlah produksi tomat apel (X1) dan biaya produksi (X2) sebagai variabel bebas dan jumlah pendapatan usahatani tomat apel (Y) sebagai variabel tak bebas. Dengan menggunakan bantuan paket program 
komputer mikrosof excel, maka model regresi berganda dapat di hitung dengan mudah dan cepat berkat pengujian estimasinya.

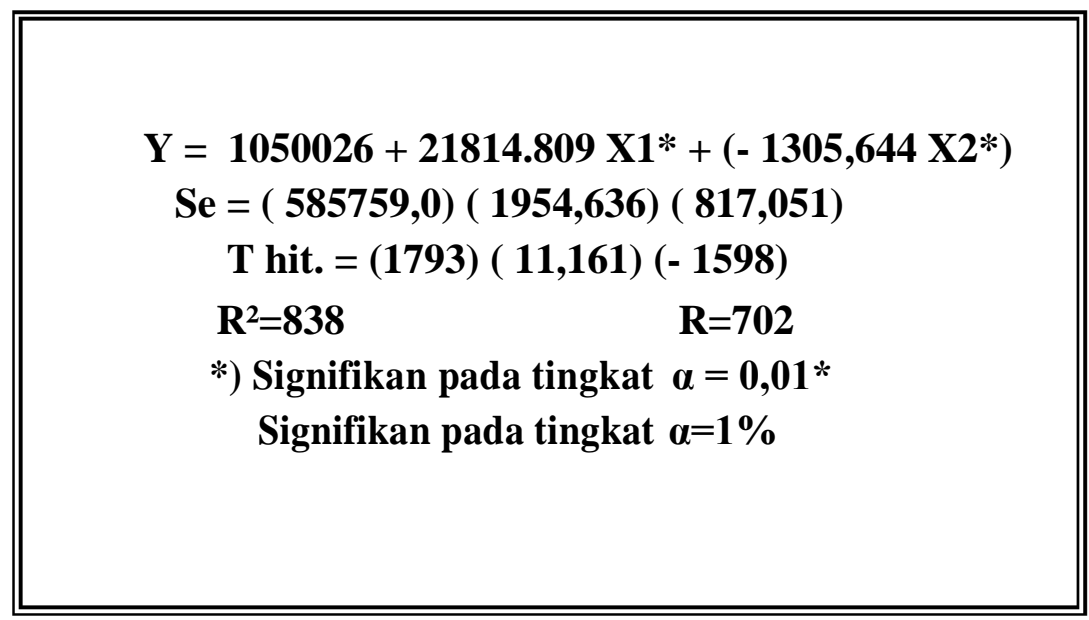

Dari perhitungan seperti yang terlihat di atas, hasil penelitian menunjukan bahwa penduga parameter jumlah produksi tomat apel mempunyai mengaruh positif yang signifikan terhadap tingkat pendapatan usahatani tomat apel pada tingkat $\alpha=0,01$. Besarnya pengaruh atau elastisitas variabel bebas ( jumlah produksi tomat apel) terhadap variabel terikat ( pendapatan usahatani tomat apel) yaitu 21814.809 berarti apabila jumlah produksi naik sebesar $1 \%$ maka di harapkan pendapatan usahatani tomat apel naik sebesar $21814.809 \%$ ceteris paribus dengan asumsi faktor-faktor lain dianggap tetap.

Hasil penelitian menunjukan bahwa pendugaan parameter biaya produksi tomat menunjukan tanda negatif dan mempunyai pengaruh yang signifikan terhadap pendapatan usahatani tomat apel pada tingkat $\alpha=0,01$. Besarnya pengaruh atau elastisitas biaya tomat apel terhadap pendapatan usahatani tomat adalah - 1305,644 berarti apabila biaya produksi tomat berkurang dari $1 \%$ maka pendapatan usahatani tomat turun sebesar $\mathbf{1 3 0 5 , 6 4 4} \%$ ceteris paribus dengan asumsi faktor-faktor lain dianggap tetap.

\section{KESIMPULAN DAN SARAN}

\subsection{Kesimpulan}

Berdasarkan hasil penelitian dan pembahasan maka ditarik kesimpulan sebagai berikut :

1. Usahatani tomat apel di Kecamatan Tompaso sudah maju dimana petani dalam pembudidayaan tomat apel sudah menggunakan benih unggul dan menggunakan sarana pertanian lainnya. 
2. Hasil penelitian menunjukan bahwa jumlah produksi dan biaya produksi mempunyai pengaruh terhadap pendapatan usahatani tomat apel yang signifikan.

3. Hasil penelitian menunjukan bahwa nilai $R$ sebesar 702 , hal ini menunjukkan bahwa jumlah produksi tomat apel dan biaya produksi mempunyai hubungan erat dengan pendapatan usahatani tomat apel oleh petani.

4. Hasil penelitian menunjukan bahwa $R^{2}$ sebesar 838 , hal ini menunjukan besarnya sumbangan/proposi jumlah produksi dan biaya produksi tomat apel terhadap variasi naik turunya pendapatan usahatani tomat sebesar 84 \% sedangkan sisanya sebesar $16 \%$ akan dijelaskan oleh faktor-faktor lain yang mempengaruhinya, yang tidak dimasukan dalam model ini.

5. Hasil penelitian menunjukan bahwa pendapatan bersih dari masing-masing lahan berbeda-beda, pendapatan bersih dengan lahan $<1$ adalah sebesar Rp. 6.073.000, pendapatan bersih dengan lahan $=1$ adalah sebesar Rp. 11.077.000 dan pendapatan bersih dengan lahan > 1 adalah sebesar Rp. 11.167.000.

\subsection{Saran}

Untuk menjaga mutu buah tomat apel dalam pemasarannya serta bagaimana hasil produksi tomat apel dapat ditingkatkan maka direkomendasikan sebagai berikut:

1. Untuk pengepakan tomat apel, terutama yang dipasarkan agak jauh dengan menggunakan angkutan darat lebih baik menggunakan kas daripada karung, sebab jika menggunakan karung buah akan cepat rusak atau busuk, tetapi jika menggunakan kas akan tahan terhadap benturan dan buah tidak cepat rusak dan busuk.

2. Perlu adanya penyuluhan tentang hama dan penyakit yang terus berubah jenisnya serta mengalami tingkat kekebalan, saat ini sering menyerang tanaman, khususnya tomat apel.

\section{DAFTAR PUSTAKA}

Gunawan Sumodiningrat, 2003/2004, Pengantar Ekonometrika, Penerbit BPFE, Yogyakarta.

Sarwoko, 2005, Dasar-Dasar Ekonometrika, Penerbit Andi, Yogyakarta. Soekartawi, 1995, Analisis Usahatani, Universitas Indonesia, Jakarta. Sudarman, A., 1994, Teori Ekonomi Mikro BPFE, Yogyakarta.

Sujanah, 1996, Teknik Analisis Regresi dan Korelasi bagi Peneliti, Penerbit Tarsito, Bandung.

Sukirno, Sadono, 2002, Pengantar Teori Mikro Ekonomi, Edisi 3, Penerbit PT. Raja Grafindo Persada, Jakarta. 


\section{Lampiran}

\section{Model Summary}

\begin{tabular}{|l|r|r|r|r|}
\hline Model & \multicolumn{1}{|c|}{$\mathrm{R}$} & R Square & $\begin{array}{l}\text { Adjusted } \\
\text { R Square }\end{array}$ & $\begin{array}{c}\text { Std. Error of } \\
\text { the Estimate }\end{array}$ \\
\hline 1 & $.838^{\mathrm{a}}$ & .702 & .692 & 1449529.85 \\
\hline
\end{tabular}

a. Predictors: (Constant), x2, x1

\begin{tabular}{|c|c|c|c|c|c|c|}
\hline \multicolumn{7}{|c|}{ ANOVA $^{b}$} \\
\hline Model & & $\begin{array}{l}\text { Sum of } \\
\text { Squares }\end{array}$ & $d f$ & Mean Square & $\mathrm{F}$ & Sig. \\
\hline \multirow{3}{*}{1} & Regression & $2.83 E+14$ & 2 & $1.413 \mathrm{E}+14$ & 67.233 & $.000^{\mathrm{a}}$ \\
\hline & Residual & $1.20 \mathrm{E}+14$ & 57 & $2.101 \mathrm{E}+12$ & & \\
\hline & Total & $4.02 \mathrm{E}+14$ & 59 & & & \\
\hline
\end{tabular}

a. Predictors: (Constant), x2, x1

b. Dependent Variable: $y$

\section{Coefficients $^{a}$}

\begin{tabular}{ll|r|r|r|r|r|}
\hline & & \multicolumn{2}{|c|}{$\begin{array}{c}\text { Unstandardized } \\
\text { Coefficients }\end{array}$} & $\begin{array}{c}\text { Standardized } \\
\text { Coefficients }\end{array}$ & \\
\cline { 3 - 5 } Model & \multicolumn{1}{|c|}{$\mathrm{B}$} & Std. Error & \multicolumn{1}{c|}{ Beta } & \multicolumn{1}{c|}{$\mathrm{t}$} & \multicolumn{1}{c|}{ Sig. } \\
\hline 1 & (Constant) & 1050026 & 585759.0 & & 1.793 & .078 \\
& x1 & 21814.809 & 1954.636 & .881 & 11.161 & .000 \\
& x2 & -1305.644 & 817.051 & -.126 & -1.598 & .116 \\
\hline
\end{tabular}

a. Dependent Variable: $y$

\section{Correlations}

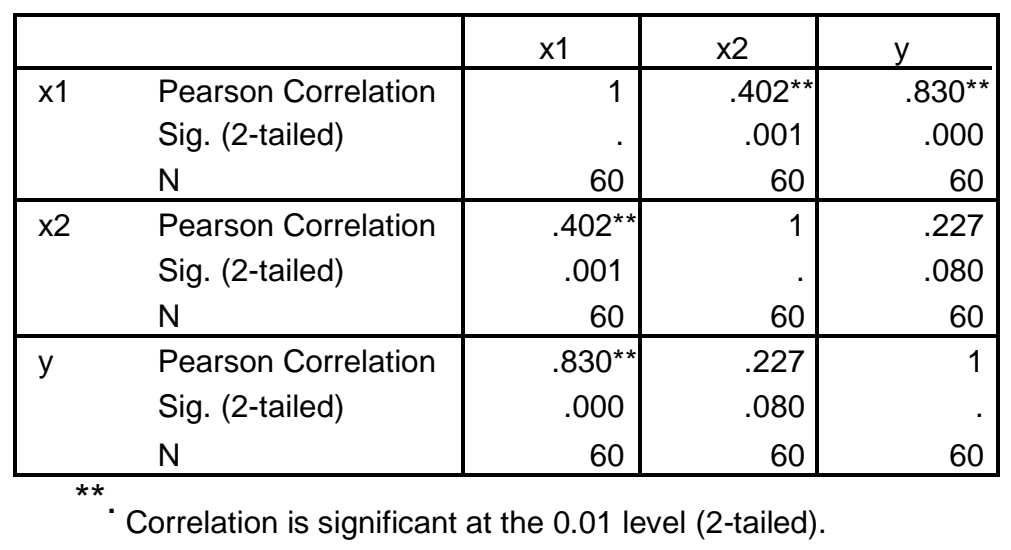

\begin{tabular}{|c|c|c|c|c|c|}
\hline $\mathbf{x 1}$ & $\mathbf{x 2}$ & $\mathbf{y}$ & $\log \mathbf{x 1}$ & $\log \mathbf{x}$ & $\log \mathbf{y}$ \\
\hline 200 & 25 & $6,737,500$ & 2.301 & 1.398 & 6.828 \\
\hline 200 & 280 & $6,737,500$ & 2.301 & 2.447 & 6.828 \\
\hline 150 & 280 & $4,237,500$ & 2.176 & 2.447 & 6.627 \\
\hline 150 & 70 & $4,237,500$ & 2.176 & 1.845 & 6.627 \\
\hline 160 & 70 & $4,737,500$ & 2.204 & 1.845 & 6.676 \\
\hline 175 & 70 & $5,237,500$ & 2.243 & 1.845 & 6.719 \\
\hline
\end{tabular}




\begin{tabular}{|c|c|c|c|c|c|}
\hline 200 & 210 & $6,737,500$ & 2.301 & 2.322 & 6.828 \\
\hline 200 & 285 & $6,737,500$ & 2.301 & 2.455 & 6.828 \\
\hline 150 & 150 & $4,237,500$ & 2.176 & 2.176 & 6.627 \\
\hline 150 & 30 & $4,237,500$ & 2.176 & 1.477 & 6.627 \\
\hline 175 & 180 & $5,237,500$ & 2.243 & 2.255 & 6.719 \\
\hline 175 & 120 & $5,237,500$ & 2.243 & 2.079 & 6.719 \\
\hline 175 & 150 & $5,237,500$ & 2.243 & 2.176 & 6.719 \\
\hline 200 & 60 & $6,737,500$ & 2.301 & 1.778 & 6.828 \\
\hline 200 & 120 & $6,737,500$ & 2.301 & 2.079 & 6.828 \\
\hline 160 & 437 & $4,737,500$ & 2.204 & 2.640 & 6.676 \\
\hline 160 & 350 & $4,737,500$ & 2.204 & 2.544 & 6.676 \\
\hline 200 & 150 & $6,737,500$ & 2.301 & 2.176 & 6.828 \\
\hline 200 & 62.5 & $6,737,500$ & 2.301 & 1.796 & 6.828 \\
\hline 160 & 525 & $4,737,500$ & 2.204 & 2.720 & 6.676 \\
\hline 350 & 525 & $7,032,500$ & 2.544 & 2.720 & 6.847 \\
\hline 340 & 140 & $7,032,500$ & 2.531 & 2.146 & 6.847 \\
\hline 350 & 140 & $7,032,500$ & 2.544 & 2.146 & 6.847 \\
\hline 300 & 140 & $4,532,500$ & 2.477 & 2.146 & 6.656 \\
\hline 325 & 750 & $5,782,500$ & 2.512 & 2.875 & 6.762 \\
\hline 340 & 420 & $6,532,500$ & 2.531 & 2.623 & 6.815 \\
\hline 350 & 570 & $7,032,500$ & 2.544 & 2.756 & 6.847 \\
\hline 340 & 150 & $7,032,500$ & 2.531 & 2.176 & 6.847 \\
\hline 330 & 60 & $6,032,500$ & 2.519 & 1.778 & 6.780 \\
\hline 320 & 360 & $6,032,500$ & 2.505 & 2.556 & 6.780 \\
\hline 310 & 240 & $5,032,500$ & 2.491 & 2.380 & 6.702 \\
\hline 320 & 390 & $5,532,500$ & 2.505 & 2.591 & 6.743 \\
\hline 340 & 120 & $6,532,500$ & 2.531 & 2.079 & 6.815 \\
\hline 340 & 300 & $6,532,500$ & 2.531 & 2.477 & 6.815 \\
\hline 300 & 875 & $4,532,500$ & 2.477 & 2.942 & 6.656 \\
\hline 350 & 700 & $7,032,500$ & 2.544 & 2.845 & 6.847 \\
\hline 325 & 87.5 & $5,782,500$ & 2.512 & 1.942 & 6.762 \\
\hline 310 & 980 & $5,032,500$ & 2.491 & 2.991 & 6.702 \\
\hline 350 & 980 & $7,032,500$ & 2.544 & 2.991 & 6.847 \\
\hline 320 & 175 & $5,532,500$ & 2.505 & 2.243 & 6.743 \\
\hline 400 & 175 & $9,387,500$ & 2.602 & 2.243 & 6.973 \\
\hline 410 & 210 & $9,887,500$ & 2.613 & 2.322 & 6.995 \\
\hline 375 & 360 & $8,137,500$ & 2.574 & 2.556 & 6.910 \\
\hline 380 & 700 & $8,387,500$ & 2.580 & 2.845 & 6.924 \\
\hline 385 & 950 & $8,637,500$ & 2.585 & 2.978 & 6.936 \\
\hline 400 & 570 & $9,387,500$ & 2.602 & 2.756 & 6.973 \\
\hline 450 & 100 & $11,887,500$ & 2.653 & 2.000 & 7.075 \\
\hline 450 & 540 & $11,887,500$ & 2.653 & 2.732 & 7.075 \\
\hline 500 & 360 & $14,387,500$ & 2.699 & 2.556 & 7.158 \\
\hline 450 & 600 & $11,887,500$ & 2.653 & 2.778 & 7.075 \\
\hline 410 & 300 & $9,387,500$ & 2.613 & 2.477 & 6.973 \\
\hline 375 & 510 & $8,137,500$ & 2.574 & 2.708 & 6.910 \\
\hline 380 & 150 & $8,387,500$ & 2.580 & 2.176 & 6.924 \\
\hline
\end{tabular}



(PEKD) Volume 17 No.1 Edisi Oktober 2015

\begin{tabular}{|c|c|c|c|c|c|}
\hline 400 & 175 & $9,387,500$ & 2.602 & 2.243 & 6.973 \\
\hline 420 & 540 & $10,387,500$ & 2.623 & 2.732 & 7.017 \\
\hline 500 & 540 & $14,387,500$ & 2.699 & 2.732 & 7.158 \\
\hline 400 & 360 & $9,387,500$ & 2.602 & 2.556 & 6.973 \\
\hline 437 & 390 & $11,237,500$ & 2.640 & 2.591 & 7.051 \\
\hline 400 & 390 & $9,387,500$ & 2.602 & 2.591 & 6.973 \\
\hline 500 & 570 & $14,387,500$ & 2.699 & 2.756 & 7.158 \\
\hline
\end{tabular}

\begin{tabular}{|c|c|c|c|c|c|c|}
\hline Kabupaten/Kota & $\begin{array}{l}\text { Perkapita } \\
\text { Provinsi }\end{array}$ & $\begin{array}{l}\text { Perkapita } \\
\text { Kota/Kab }\end{array}$ & $\begin{array}{c}\text { Jumlah } \\
\text { Penduduk } \\
\text { Provinsi } \\
\end{array}$ & $\begin{array}{c}\text { Jumlah } \\
\text { Penduduk } \\
\text { Kota/Kab } \\
\end{array}$ & $\frac{(\mathbf{Y i}-\mathbf{Y})^{2} \mathbf{f i} / \mathbf{n}}{Y}$ & $\frac{\sum(\mathbf{Y i}-}{\frac{\mathrm{Y})^{2}}{\frac{\mathbf{f i} / \mathbf{n}}{\mathbf{Y}}}}$ \\
\hline \multicolumn{7}{|l|}{ Kabupaten } \\
\hline 01 Bolaang Mongondow & $\mathbf{5 , 9 4 7 , 8 5 2 , 5 1 7}$ & $3,032,593$ & 2275119 & 293167 & 765646289 & 0,12 \\
\hline 02 Minahasa & $\mathbf{5 , 9 4 7 , 8 5 2 , 5 1 7}$ & $5,797,663$ & 2275119 & 293081 & 764709824 & 0,12 \\
\hline 03 Kepulauan Sangihe & $\mathbf{5 , 9 4 7 , 8 5 2 , 5 1 7}$ & $4,556,368$ & 2275119 & 130079 & 339545222 & 0,05 \\
\hline 04 Kepulauan Talaud & $5,947,852,517$ & $4,562,290$ & 2275119 & 74660 & 194884614 & $\mathbf{0 , 0 3}$ \\
\hline 05 Minahasa Selatan & $\mathbf{5 , 9 4 7 , 8 5 2 , 5 1 7}$ & $5,514,742$ & 2275119 & 181957 & 474809203 & 0,07 \\
\hline 06 Minahasa Utara & $\mathbf{5 , 9 4 7 , 8 5 2 , 5 1 7}$ & $6,085,666$ & 2275119 & 170340 & 444409718 & $\mathbf{0 , 0 7}$ \\
\hline 07 Bolaang Mongondow Utara & $5,947,852,517$ & $3,750,093$ & 2275119 & 77690 & 202849238 & $\mathbf{0 , 0 3}$ \\
\hline 08 Kepulauan Sitaro Siau & $\mathbf{5 , 9 4 7 , 8 5 2 , 5 1 7}$ & $3,834,966$ & 2275119 & 61552 & 160708196 & 0,02 \\
\hline 09 Minahasa Tenggara & $\mathbf{5 , 9 4 7 , 8 5 2 , 5 1 7}$ & $7,190,545$ & 2275119 & 94971 & 247683106 & $\mathbf{0 , 0 4}$ \\
\hline $\begin{array}{l}\text { 10 Bolaang Mongondow } \\
\text { Selatan }\end{array}$ & $\mathbf{5 , 9 4 7 , 8 5 2 , 5 1 7}$ & $3,969,895$ & 2275119 & 53682 & 140153784 & 0,02 \\
\hline $\begin{array}{l}11 \text { Bolaang Mongondow } \\
\text { Timur }\end{array}$ & $\mathbf{5 , 9 4 7 , 8 5 2 , 5 1 7}$ & $5,040,198$ & 2275119 & 60796 & 158669966 & 0,02 \\
\hline \multicolumn{7}{|l|}{ Kota } \\
\hline 71 Manado & $\mathbf{5 , 9 4 7 , 8 5 2 , 5 1 7}$ & $\mathbf{9 , 8 5 5 , 0 7 0}$ & 2275119 & 417654 & 1088259206 & 0,18 \\
\hline 72 Bitung & $\mathbf{5 , 9 4 7 , 8 5 2 , 5 1 7}$ & $10,403,520$ & 2275119 & 169243 & 440906184 & 0,07 \\
\hline 73 Tomohon & $\mathbf{5 , 9 4 7 , 8 5 2 , 5 1 7}$ & $6,267,727$ & 2275119 & 81882 & 213613518 & 0,03 \\
\hline 74 Kotamubagu & $\mathbf{5 , 9 4 7 , 8 5 2 , 5 1 7}$ & $3,026,754$ & 2275119 & 114365 & 298680649 & 0,05 \\
\hline
\end{tabular}

